\title{
A Late Neoproterozoic age for a tonalite dyke in the Boisdale Hills, Cape Breton Island, Nova Scotia
}

\author{
Sandra M. Barr ${ }^{1}$, Sandra Kamo ${ }^{2}$, and Chris E. White ${ }^{3}$ \\ ${ }^{I}$ Department of Geology, Acadia University, Wolfville, Nova Scotia BOP 1X0, Canada \\ ${ }^{2}$ Royal Ontario Museum, 100 Queen's Park, Toronto Ontario M5S 2C6, Canada \\ ${ }^{3}$ Department of Natural Resources, P.O. Box 698, Halifax, \\ Nova Scotia B3J 2T9, Canada \\ Date Received: October 18, 1999 \\ Date Accepted: May 1, 2000
}

\begin{abstract}
A tonalite dyke in the Benacadie Brook Formation in the Boisdale Hills of central Cape Breton Island yielded a U-Pb (zircon) age of $564.5 \pm 5.1 \mathrm{Ma}$, interpreted to be the age of intrusion. The age is identical within error to the U-Pb (zircon) age of $564+3 /-2$ Ma previously reported for a granodiorite sample from the nearby Shunacadie Pluton. Based on geographic proximity and identical age, as well as petrological similarities, the tonalite dyke is interpreted to be comagmatic with the granodiorite. Although the new date does not provide further constraint on the age of the Benacadie Brook Formation, it affirms the importance of ca. 560 Ma plutonism in the Bras d'Or terrane of Cape Breton Island.
\end{abstract}

Un dyke de tonalite intrusive dans la formation de Benacadie Brook, dans les collines du centre de l'île du Cap-Breton, a révélé une datation au U-Pb (au zircon) de 564,5 $\pm 5,1$ m.a. Cette datation est la même que celle obtenue au U-Pb (au zircon) de $564+3 /-2$ m.a. signalée précédemment pour un échantillon de granodiorite de la formation plutonique adjacente de Shunacadie. Compte tenu de la proximité géographique, du même âge et d'autres similitudes pétrologiques, ce dyke de tonalite est réputé appartenir à la même province pétrographique que la granodiorite. Bien que cette nouvelle datation ne donne pas d'autres précisions sur l'âge de la formation de Benacadie Brook, elle n'en établit pas moins l'importance de l'activité plutonique survenue dans le terrane du Bras d'Or sur l'île du Cap-Breton il y a environ 560 m.a.

Traduit par la rédaction

\section{INTRODUCTION}

The Boisdale Hills of south-central Cape Breton Island (Fig. 1) are underlain by northeast-trending belts of Late Neoproterozoic or older metamorphic and plutonic rocks, and Cambrian to Ordovician volcanic, sedimentary, and minor plutonic rocks (e.g., Bell and Goranson 1938; Milligan 1970; Barr and Setter 1986; White et al. 1994). The purpose of this note is to present a new $\mathrm{U}-\mathrm{Pb}$ (zircon) age, as well as petrographic and chemical data, from a tonalitic dyke in the metamorphic rocks. The dyke was dated in an attempt to better constrain the minimum age of the host metamorphic rocks, previously indicated by a U-Pb (zircon) age of $564+3 /-2 \mathrm{Ma}$ from granodiorite of the Shunacadie Pluton (Barr et al. 1990). Although the age reported here is identical, within error, to that of the previously dated granodiorite and hence does not provide enhanced constraint on the age of its host rocks, it provides further corroboration for the age of plutonic units in the Bras d'Or terrane of Cape Breton Island (Fig. 1).

\section{GeOLOGICAL SETTING}

The metamorphic rocks of the Boisdale Hills were included in the George River Series of Milligan (1970) and George River Group of Keppie (1979). As a result of detailed petrographic study, Raeside (1989) and Raeside and Barr
(1990) divided the metamorphic rocks into two suites, a higher grade Frenchvale Road metamorphic suite and a lower grade Benacadie Brook Formation. The relationship between these two units is uncertain because they are everywhere separated by major faults and/or younger units (Fig. 1).

The age of these metamorphic units is also uncertain. The minimum age is constrained by the ages of plutonic units intruded into them, oldest of which is the U-Pb (zircon) age of granodiorite in the Shunacadie Pluton (Barr et al. 1990). The Benacadie Brook Formation, which mainly hosts the Shunacadie Pluton (Fig. 1), is similar to relatively low-grade metasedimentary units scattered throughout the Bras d'Or terrane, collectively termed the George River Metamorphic Suite by Keppie et al. (1998). The age of these metasedimentary rocks is mainly constrained by plutons similar in age to or younger than the Shunacadie Pluton (Raeside and Barr 1990; Keppie et al. 1998), although Keppie et al. (1998) reported detrital zircon ages as young as $637 \mathrm{Ma}$ from volcanogenic units in the Creignish Hills $(\mathrm{CH}$; Fig. 1) inferred to be part of the George River Metamorphic Suite. However, the depositional age of possibly correlative units in northern mainland Nova Scotia and southern New Brunswick has been suggested to be as old as middle Riphean (Hofmann 1974), and hence the age of units such as the Benacadie Brook Formation is important for regional correlations and tectonic reconstructions (e.g., Keppie et al. 1998). 


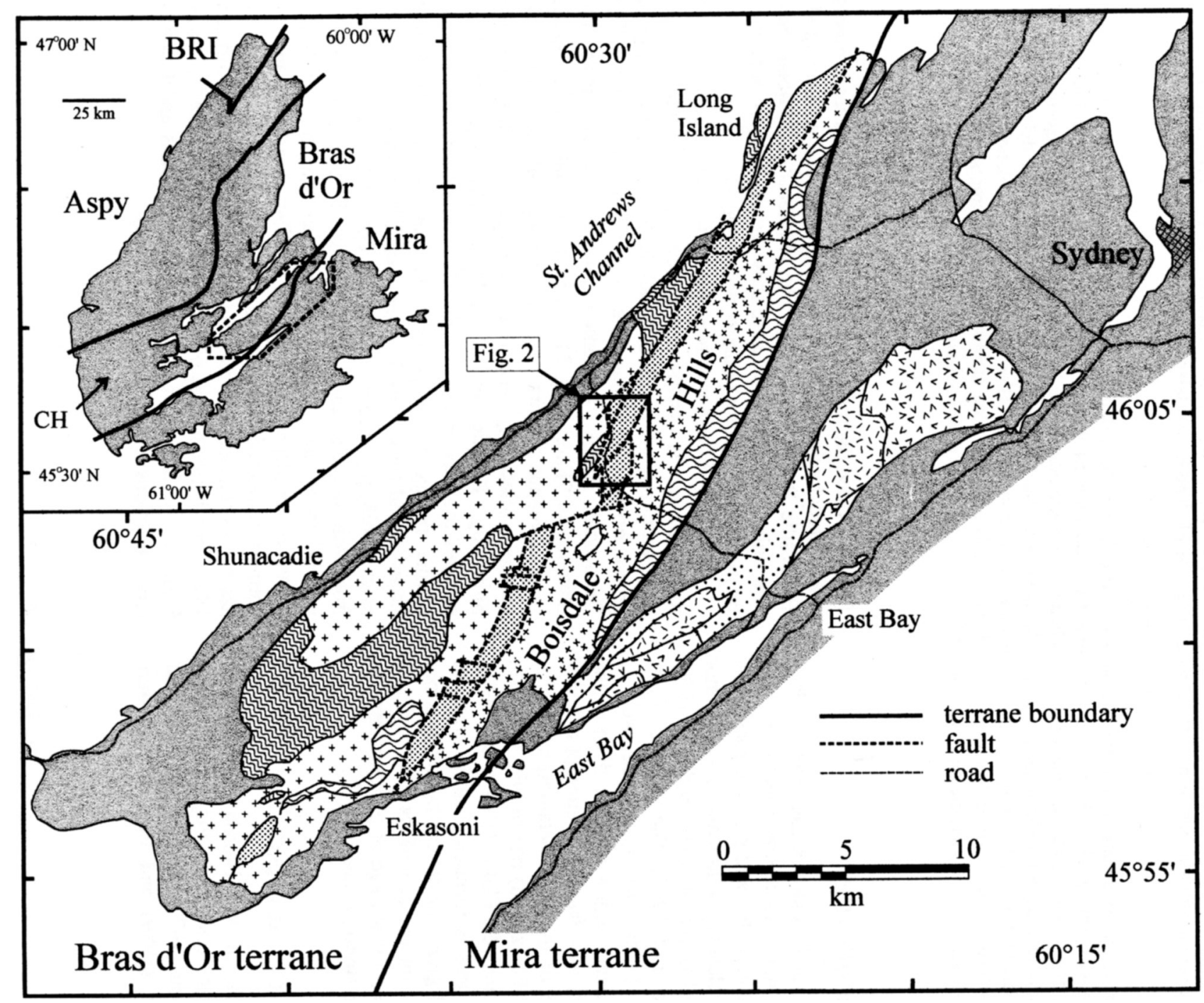

Devonian-Carboniferous

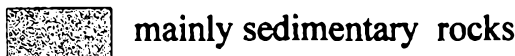

\section{BRAS D'OR TERRANE}

Cambrian-Ordovician

\section{Bourinot belt}

\%olcanic and sedimentary rocks

\section{Cambrian}

$\left[x^{x} x^{x} x^{x} x^{x}\right.$ Mount Cameron Syenogranite

Late Neoproterozoic

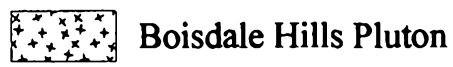

$[+++]$ Shunacadie Pluton

Late Neoproterozoic or Older

鹠

$\approx$ ₹ $\approx$ Frenchvale Road metamorphic suite

\section{MIRA TERRANE}

Cambrian-Ordovician

$\therefore \because$ sedimentary rocks

Late Neoproterozoic

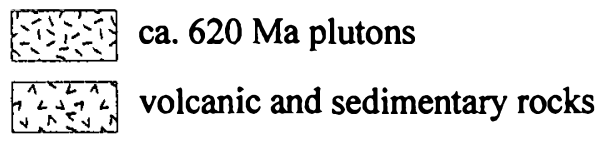

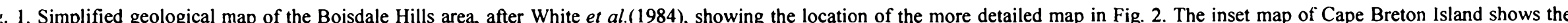

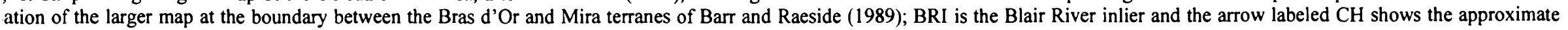
ation of the Creignish Hills referred to in the text. 


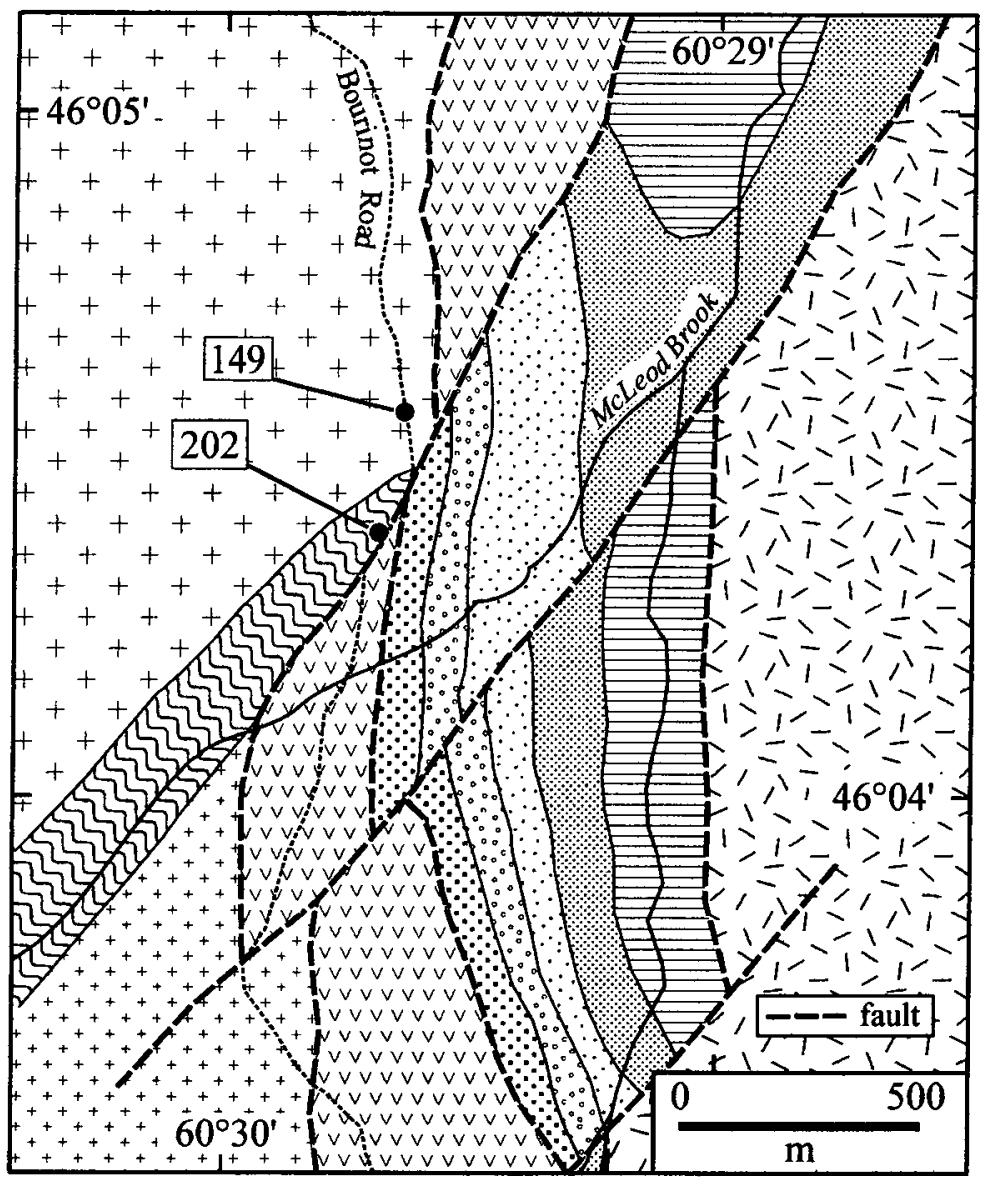

Ordovician

McLeod Brook Formation

\section{Upper Cambrian}

?. MacNeil Formation

\section{Middle Cambrian}

\begin{tabular}{|c|c|}
\hline$\because \because$ & MacMullin Formation \\
\hline & Gregwa Formation \\
\hline & Dugald Formation \\
\hline$\vee \vee v$ & Eskasoni Formatio \\
\hline
\end{tabular}

Late Neoproterozoic

Boisdale Hills Pluton

E>17 granite, granodiorite

Shunacadie Pluton

$++_{++}^{+}$granite
+++ granodiorite

Late Neoproterozoic or Older

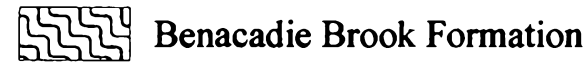

Fig. 2. Geological map of the central Boisdale Hills showing the location of the dated tonalite dyke (sample 202) and sample 149 from near the margin of the Shunacadie Pluton. Geology is after White et al. (1994); the Middle Cambrian to Ordovician formations listed in the legend constitute the Bourinot belt of Fig. 1 .

Plutonic rocks of the Boisdale Hills were studied in detail by Barr and Setter (1986). They divided the rocks into two large plutons, Shunacadie and Boisdale Hills, separated by volcanic and sedimentary rocks of the Bourinot belt and by major faults (White et al. 1994). The Shunacadie Pluton consists mainly of biotite granodiorite, with minor areas of diorite, granite, and leucogranite. The age of the pluton is 564 $+3 /-2 \mathrm{Ma}$, based on U-Pb (zircon) dating of the biotite granodiorite unit (Barr et al. 1990). The components of the Boisdale Hills Pluton range from diorite, quartz diorite, and tonalite to granodiorite, monzogranite, and leucogranite (Barr and Setter 1986). The minimum age of the Boisdale Hills Pluton is constrained by ${ }^{40} \mathrm{Ar} /{ }^{39} \mathrm{Ar}$ cooling ages for hornblende of ca. $530 \mathrm{Ma}$ (Keppie et al. 1990). Earlier $\mathrm{Rb}-\mathrm{Sr}$ results ranging from ca. 502 to $563 \mathrm{Ma}$ (e.g., Cormier 1972; Wanless et al. 1968) have large errors and are not considered reliable (Barr et al. 1990). Barr and Setter (1986) also included the Mount Cameron Syenogranite (Fig. 1) in the Boisdale Hills Pluton, but it was subsequently shown to be a petrologically distinct and younger pluton with a U-Pb (zircon) age of $509 \pm 2$ Ma (White et al. 1994).

\section{TONALITE DYKES}

The dyke that is the focus of the present study is one of two dykes of tonalitic composition that intruded an outcrop of metasedimentary rocks about $100 \mathrm{~m}$ in extent along the Bourinot Road (Fig. 2). The metasedimentary rocks that host the dykes appear to form a large xenolith or roof pendant in the Shunacadie Pluton, and are correlated on the basis of lithology with the Benacadie Brook Formation of Raeside and Barr (1990). On the east, the metamorphic rocks are in faulted contact with rocks of the Eskasoni Formation, the lowermost unit of the Cambrian-Ordovician Bourinot Group (White et al. 1994).

The metamorphic rocks consist of fine- to mediumgrained hornfels, containing mainly quartz and plagioclase together with about $15 \%$ scattered, randomly oriented biotite flakes. Garnet forms rare porphyroblasts.

The two tonalite dykes that cut the hornfels are each 5 $10 \mathrm{~m}$ wide, and consist mainly of medium-grained anhedral plagioclase and quartz, and clusters of small biotite flakes. They contrast with the adjacent granodiorite of the Shunacadie Pluton, which has a well-preserved hypidiomorphic granular (igneous) texture. The texture of the dykes suggests that they have been recrystallized, together with their host metasedimentary rocks, by the thermal effects of the adjacent Shunacadie Pluton, and/or by interaction with hot fluids derived from the pluton or the host rocks.

Similar tonalitic dykes were also observed in a small area of metamorphic rocks north of Eskasoni, $12 \mathrm{~km}$ to the 
Table 1. Chemical data

\begin{tabular}{lrrr}
\hline wt. \% & BHC91-202 & BHC91-149 & Average $^{2}$ \\
\hline $\mathrm{SiO}_{2}$ & 67.03 & 70.35 & 67.53 \\
$\mathrm{TiO}_{2}$ & 0.60 & 0.48 & 0.49 \\
$\mathrm{Al}_{2} \mathrm{O}_{3}$ & 16.19 & 15.93 & 15.49 \\
$\mathrm{Fe}_{2} \mathrm{O}_{3}{ }^{\mathrm{t}}$ & 4.64 & 3.43 & 3.87 \\
$\mathrm{MnO}$ & 0.10 & 0.08 & 0.09 \\
$\mathrm{MgO}$ & 2.38 & 1.57 & 1.45 \\
$\mathrm{CaO}$ & 2.05 & 1.00 & 2.80 \\
$\mathrm{Na}{ }^{2} \mathrm{O}$ & 4.04 & 5.42 & 3.77 \\
$\mathrm{~K}_{2} \mathrm{O}$ & 0.93 & 0.67 & 2.46 \\
$\mathrm{P}_{2} \mathrm{O}_{5}$ & 0.13 & 0.11 & 0.11 \\
$\mathrm{LOI}$ & 2.50 & 2.00 & 1.47 \\
$\mathrm{TOTAL}$ & 100.59 & 101.04 & 99.67 \\
& & & \\
$\mathrm{ppm}$ & & & \\
$\mathrm{Ba}$ & 275 & 122 & 397 \\
$\mathrm{Rb}$ & 42 & 26 & 78 \\
$\mathrm{Sr}$ & 223 & 236 & 217 \\
$\mathrm{Y}$ & 35 & 20 & 28 \\
$\mathrm{Zr}$ & 161 & 134 & 155 \\
$\mathrm{Nb}$ & 12 & 7 & 11 \\
$\mathrm{Th}$ & 10 & 10 & 11 \\
$\mathrm{~Pb}$ & 15 & 10 & 10 \\
$\mathrm{Ga}$ & 15 & 12 & 15 \\
$\mathrm{Zn}$ & 133 & 42 & 60 \\
$\mathrm{Cu}$ & 91 & 7 & 8 \\
$\mathrm{Ni}$ & 17 & 14 & 16 \\
$\mathrm{~V}$ & 94 & 57 & 69 \\
$\mathrm{Cr}$ & 30 & 33 & 45 \\
\hline
\end{tabular}

'Analyses by standard X-Ray Fluorescence techniques at the Regional Geochemical Centre, St. Mary's University, Halifax, NS, except major element data for calculation of the average for the Shunacadie granodiorite is taken from Barr and Setter (1986).

${ }^{2}$ Average of 22 analyses of samples from the granodiorite unit, Shunacadie Pluton; samples from Barr and Setter (1986).

southwest of the Bourinot Road section (Fig. 1). That area of metamorphic rocks was assigned to the Frenchvale Road metamorphic suite by Raeside (1989) and Raeside and Barr (1990).

Chemical analysis of a sample from the dated dyke (BHC91-202; Table 1) shows low $\mathrm{K}_{2} \mathrm{O}(0.93 \%)$, consistent with its tonalitic modal mineralogy. Also shown in Table 1 is a chemical analysis of sample 149, collected from the granodioritic unit of the Shunacadie Pluton approximately 200 $\mathrm{m}$ north of the tonalite dyke (Fig. 2). Although superficially more similar in appearance to typical granodiorite of the Shunacadie Pluton, rather than to the tonalite dykes, sample 149 contains little or no K-feldspar and has chemical composition similar to that of dyke sample BHC91-202 (Table 1). The similarity is also illustrated on a multi-element variation diagram (Fig. 3). Compared to the average of 22

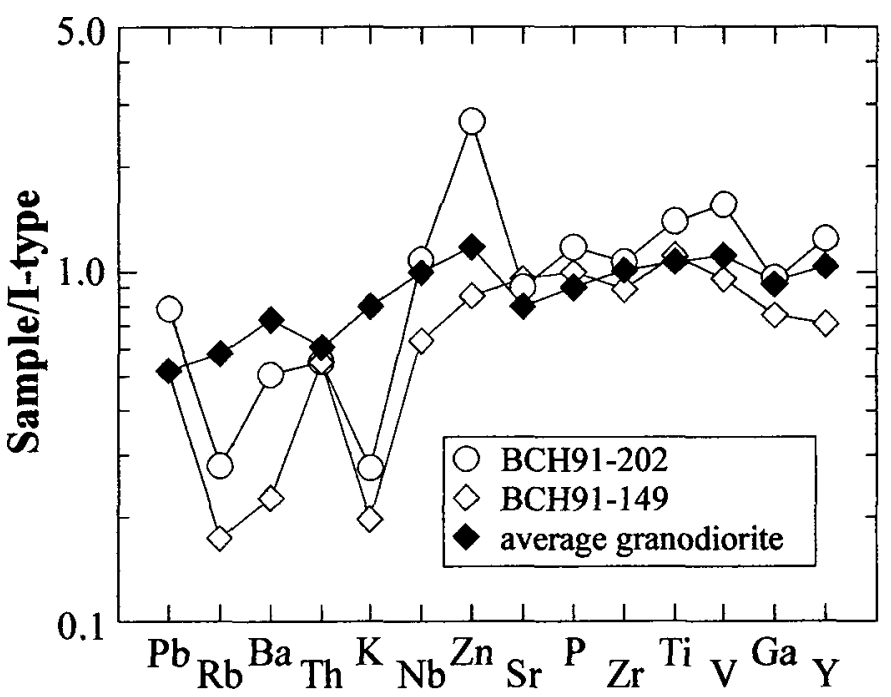

Fig. 3. Multi-element variation diagram with data from Table 1 normalized to average I-type granite of Whalen et al. (1987).

analyses of samples from the granodiorite unit of the Shunacadie Pluton (samples from Barr and Setter 1986), both the tonalite dyke sample and sample 149 have lower contents of the mobile elements such as $\mathrm{K}, \mathrm{Rb}$, and $\mathrm{Ba}$, but have similar compositions in the generally less immobile elements such as $\mathrm{P}, \mathrm{Zr}$, and $\mathrm{Ti}$ (Fig. 3). It is suggested that in both cases, the chemical differences are the result of post-crystallization alteration and metasomatism.

\section{GEOCHRONOLOGY}

\section{Analytical methods}

Zircon was separated from the tonalite sample using standard heavy liquid and magnetic separation techniques. All zircon fractions, with the exception of $\# 7$, were air abraded (Krogh 1982). Mineral dissolution and isolation of $\mathrm{U}$ and $\mathrm{Pb}$ from zircon followed the procedure of Krogh (1973), modified by using small anion exchange columns $(0.05 \mathrm{~mL}$ of resin).

$\mathrm{Pb}$ and $\mathrm{U}$ were loaded together with silica gel onto outgassed rhenium filaments. The isotopic compositions of $\mathrm{Pb}$ and $U$ were measured using a single collector Daly detector in a solid source VG354 mass spectrometer. A mass fractionation correction of $0.1 \%$ per amu for both $\mathrm{Pb}$ and $\mathrm{U}$ was used. Error estimates were calculated by propagating known sources of analytical uncertainty for each analysis, including ratio variability (within run), uncertainty in the fractionation correction $(0.038 \%$ and $0.026 \%$ at 1 sigma for $\mathrm{Pb}$ and $\mathrm{U}$, respectively, based on long-term replicate measurements of the standards NBS981 and U-500), and uncertainties in the isotopic composition and amount of laboratory blank and initial $\mathrm{Pb}$. Initial common $\mathrm{Pb}$ in excess of $10 \mathrm{pg}$ was corrected using the $\mathrm{Pb}$ evolution model of Stacey and Kramers (1975). Decay constants are those of Jaffey et al. (1971). Age errors quoted in the text and table and error ellipses in the concordia diagrams are given at the $95 \%$ confidence level. Discordia lines and intercept ages were calculated using the regression program of Davis (1982). 
Table 2. U-Pb isotopic data for zircon from tonalite dyke sample BHC92-202.

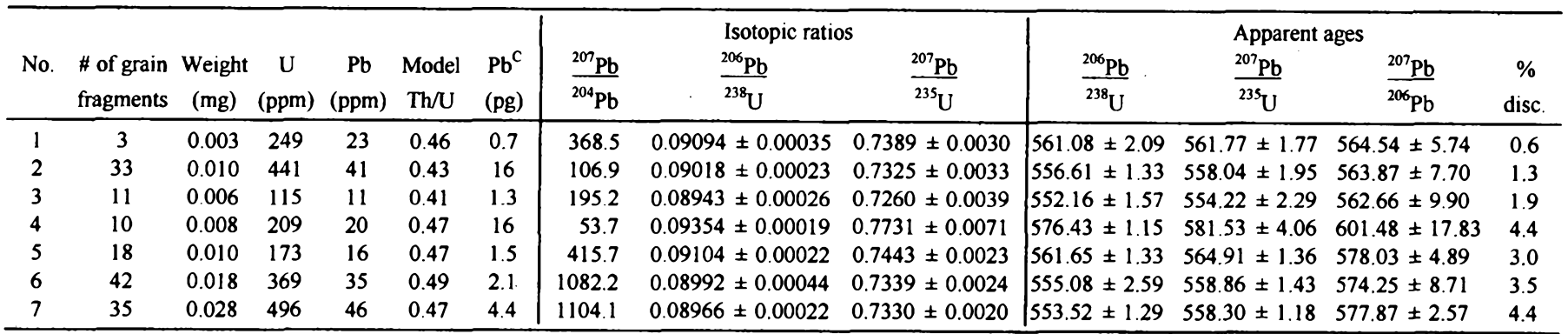

Notes: Model $\mathrm{Th} / \mathrm{U}$ from estimated Th concentration based on abundance of ${ }^{208} \mathrm{~Pb}$ and ${ }^{207} \mathrm{~Pb} /{ }^{206} \mathrm{~Pb}$ age. $\mathrm{Pb}$ is total common $\mathrm{Pb}$ from sample and laboratory procedures ${ }^{207} \mathrm{~Pb} /{ }^{204} \mathrm{~Pb}$ ratios have been corrected for spike and fractionation. $\mathrm{Pb} / \mathrm{U}$ ratios have been corrected for spike, fractionation, blank, and initial common $\mathrm{Pb}$. \% disc. is percent discordance assuming zero-age $\mathrm{Pb}$ loss. Absolute errors are 2 sigma

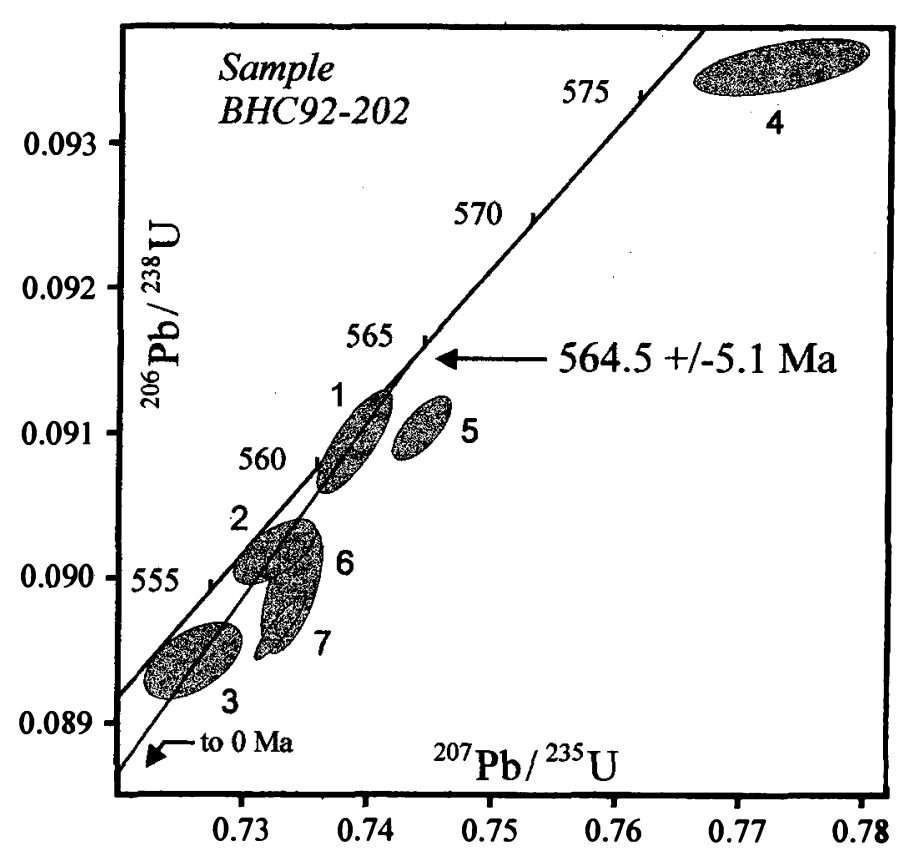

Fig. 4. Concordia diagram for zircon fractions 1 to 7 , as described in the text. Data are from Table 2.

\section{Results}

Seven multigrain zircon fractions were analyzed for $\mathrm{Pb}$ and $U$ and the data are presented in Table 2 and Fig. 4 . The zircon fractions were selected from 2 morphologically distinct subpopulations: (1) colourless, skeletal fragments (i.e. flat, bladed shards), and (2) colourless, euhedral, elongate, doubly terminated, 4-sided prismatic grains.

Data points 1, 2, and 3 are collinear and give an upper intercept age of $564.5 \pm 5.1 \mathrm{Ma}(91 \%$ probability of fit), which is interpreted as the best estimate for the age of the tonalite dyke. The data points are $0.7 \%, 1.6 \%$, and $2.4 \%$ discordant, respectively, along the $\mathrm{Pb}$-loss line toward a zeroage lower intercept. These data were obtained from fragments of skeletal grains, as were data points 5,6, and 7; however, the latter plot to the right of the Pb-loss line and it is suspected that these fractions contained minor inherited components in the form of colourless cores or as discrete grains. Data point
\#4 was produced from the second subpopulation and contains older inherited zircons that were probably acquired during emplacement of the dyke into older crust.

\section{IMPLICATIONS AND CONCLUSIONS}

The age of metamorphic units in the Bras d'Or terrane is not well constrained (e.g., Raeside and Barr 1990; Keppie et al. 1998). The tonalite dyke was sampled for dating because its petrographic features suggested that it might be an older intrusion, age of which would constrain better the minimum age of the host metamorphic rocks than the Shunacadie Pluton (U-Pb age $564+3 /-2$ Ma; Barr et al. 1990). However, the age obtained $(564.5 \pm 5.1 \mathrm{Ma})$ is identical to that of the Shunacadie Pluton, and hence does not provide further information about the minimum age of the Benacadie Brook Formation.

The apparent petrographic differences between the tonalite dykes and granodiorite of the Shunacadie Pluton, such as greater degree of recrystallization of the tonalite, may be related to its small size and interaction with the host metasedimentary rocks. This interpretation is consistent with inheritance apparent in zircon systematics in the tonalite. The overall chemical similarity between the tonalite dyke and sample 149 from near the margin of the Shunacadie Pluton suggests that interaction with the metamorphic rocks may have produced their compositional characteristics, which contrast with the average composition of granodiorite in the Shunacadie Pluton. The tonalitic dykes are inferred to be comagmatic with the granodiorite unit of the Shunacadie Pluton.

\section{ACKNOWLEDGEMENTS}

The field work and chemical analyses for this project were funded by a Research Grant to S.M. Barr from the Natural Sciences and Engineering Research Council of Canada.

We thank journal reviews Brent Miller and Brendan Murphy for their helpful comments, which led to improvements in the manuscript. 


\section{REFERENCES}

BARR, S.M., \& RAESIDE, R.P. 1989. Tectonostratigraphic terranes in Cape Breton Island, Nova Scotia. Implications for the configuration of the northem Appalachian Orogen. Geology, 17, pp. 822-825.

BARR, S.M., \& SETTER, J.R.D. 1986. Petrology of granitoid rocks of the Boisdale Hills, central Cape Breton Island, Nova Scotia. Nova Scotia Department of Mines and Energy, Paper 84-1, 75 p.

BARR, S.M., DUNNING, G.R., RAESIDE, R.P., \& JAMIESON, R.A. 1990. Contrasting U-Pb ages from plutons in the Bras d'Or and Mira terranes of Cape Breton Island, Nova Scotia. Canadian Journal of Earth Sciences, 27, pp. 1200-1208.

Bell, W.A., \& GoRanson, E.A. 1938. Sydney Sheet (West Half). Geological Survey of Canada, Department of Mines and Resources. Map 360A. Scale 1 inch to 1 mile.

CORMIER, R.F. 1972. Radiometric ages of granitic rocks, Cape Breton Island, Nova Scotia. Canadian Journal of Earth Sciences, 9, pp. 1074-1086.

DAvis, D.W. 1982. Optimum linear regression and error estimation applied to U-Pb data. Canadian Joumal of Earth Sciences, 19, 2141-2149.

HofmanN, H.J. 1974. The stromatolite Archaeozoon acadiense from the Proterozoic Green Head Group of St. John, New Brunswick. Canadian Journal of Earth Sciences, 11, pp. 1098-1115.

JAFFeY, A.H., FlynN, K.F., GlendenIN, L.F., BENTLEY, W.C., \& ESSLING, A.M. 1971. Precision measurements of half-lives and specific activities of ${ }^{235} U$ and ${ }^{238} U$, Physical Reviews C, v.4, pp. 1889-1906.

KEPPIE, J.D. 1979. Geological Map of the Province of Nova Scotia. Nova Scotia Department of Mines and Energy, scale 1:500,000.

KEPPIE, J.D., DAVIS, D.W., \& KROGH, T.E. 1998. U-Pb geochronological constraints on Precambrian stratified units in the Avalon Composite Terrane of Nova Scotia, Canada: tectonic implications. Canadian Journal of Earth Sciences, 35, pp. 222236.

KePPIE, J.D., DALlmeYER, R.D., \& MURPhy, J.B. 1990. Tectonic implications of ${ }^{40} \mathrm{Ar} /{ }^{39} \mathrm{Ar}$ homblende ages from late Proterozoic-Cambrian plutons in the Avalon Composite Terrane,
Nova Scotia, Canada. Geological Society of America Bulletin, 102, pp. 516-528.

KROGH, T.E. 1973. A low-contamination method for hydrothermal decomposition of zircon and extraction of $U$ and $T h$ for isotope age determinations. Geochimica et Cosmochimica Acta, 37, pp. 485-494.

KROGH, T.E. 1982. Improved accuracy of U-Pb ages by the creation of more concordant systems using an air abrasion technique. Geochimica et Cosmochimica Acta, 46, pp. 637-649.

Milligan, G.C. 1970. The geology of the George River Series, Cape Breton. Nova Scotia Department of Mines, Memoir 7, 111 p.

RAESIDE, R.P. 1989. Geology of the metamorphic rocks of the Boisdale Hills, Cape Breton Island. In Mines and Energy Branch Report of Activities 1989, part A. Edited by D.R. MacDonald and K.A. Mills. Nova Scotia Department of Mines and Energy, Report 89-3, pp. 145-148.

RAESIDE, R.P., \& BARR, S.M. 1990. Geology and tectonic development of the Bras d'Or suspect terrane, Cape Breton Island, Nova Scotia. Canadian Journal of Earth Sciences, 27, pp. 1371-1381.

STACEY, J.S., \& KRAMERS, J.D. 1975. Approximation of terrestrial lead isotope evolution by a two-stage model. Earth and Planetary Science Letters, 34, pp. 207-221.

Wanless, R.K., Stevens, R.D., Lachance, G.R., \& Edmonds, C.M. 1968. Age determinations and geological studies, K-Ar isotopic ages, report 8, Geological Survey of Canada Paper 67 $2 \mathrm{~A}, 141 \mathrm{p}$.

Whalen, J.B., CuRrIe, K.L., \& Chappell, B.W. 1987. A-type granites: geochemical characteristics, discrimination, and petrogenesis: Contributions to Mineralogy and Petrology, 95, pp. 407-419.

White, C.E., BARR, S.M., Bevier, M.L., \& KaMo, S. 1994. A revised interpretation of Cambrian and Ordovician rocks in the Bourinot belt of central Cape Breton Island, Nova Scotia. Atlantic Geology, 30, pp. 123-142.

Editorial responsibility: Graham L. Williams 